\title{
Listening as 'Guiding Tool' in the Continuous Improvement of University Education: A Holistic Approach
}

\author{
Dr. Ida Verna, Senior Lecturer \\ Dr. Gianluca Antonucci, Senior Lecturer \\ Prof. Massimo Sargiacomo, \\ Prof. Michelina Venditti,
}

Department of Management and Business Administration Gabriele d'Annunzio University of Chieti-Pescara, Italy

Doi:10.19044/esj.2019.v15n25p57～URL:http://dx.doi.org/10.19044/esj.2019.v15n25p57

\begin{abstract}
The quality of higher education is linked to listening and to satisfying the needs of all those involved (social partners, teachers, students, institutional bodies). The satisfaction of these needs requires a holistic approach that is capable of respecting the complex nature of teaching. In this sense, an approach called L'Ascolto has been developed, aimed precisely at listening to the needs and satisfying those needs through the design, management, evaluation and improvement of a degree course and the individual subjects that compose it, considered as a system of relationships and interdependencies. The approach is based on the TQM logic where the satisfaction of needs is pursued through a holistic approach. Given the innovative nature of the L'Ascolto, it is initially introduced and subsequently developed both in reference to the principles and methods of operation as well as in relation to other existing models.
\end{abstract}

Keywords: Holistic Approach, Teaching Quality, Continuous Improvement, TQM, Higher Education

\section{Introduction}

It is well known that the cultural and economic growth of a country is linked to the quality of education and research. The role played by the universities is therefore decisive. To this end, this study proposes an approach to university, education based on the Total Quality Management - TQM (Feigenbaum, 1956; Juran, 1962; Deming, 1951) involving the necessary scientific research indispensable for a cultural revolution of the whole 
academic system and the context in which it operates. 'Doing the right things right' (Conti, 2004) is a definition of quality, one of many in the literature that best represents the proposed approach. In L'Ascolto, 'the right things to do' (strategic effectiveness) correspond 'to listening' to the needs of all customers ${ }^{3}$ and in converting those same needs into an academic program that can satisfy them. 'Doing things right' (operational efficiency) is instead understood as optimizing the resources which the university has at its disposal (material and immaterial) in order to achieve its educational goals, fundamental processes, how they are structured (Quinn, Lemay, Larsen, \& Johnson, 2009) and the relationships that link them. In particular, L'Ascolto is an evolution of the TEM approach - Teaching Evaluation Model (Verna, 2008; Verna, 2002; Verna \& Perozzi, 2010), whose experimentation over the years (Verna \& Perozzi, 2014) has highlighted the need to integrate TEM (Verna, 2014) and extend it to the entire academic program. Today, L'Ascolto is an experimental, multidisciplinary project of the G. d'Annunzio University which is financing the creation of a web platform ${ }^{4}$ that reproduces the L'Ascolto approach based on algorithms ${ }^{5}$. The innovation that characterizes the $L$ 'Ascolto approach has led to a subdivision of the present paper in two parts: the analysis of the literature that anticipates $L$ 'Ascolto and its analysis through a comparison with existing models. Even though L'Ascolto may be applied in any educational context (elementary, high school, university, etc.), in this paper the reference is limited exclusively to university education.

\section{A Review of the TMQ Literature Concerning Higher Education: A Holistic Approach Analysis.}

In this context, it has been shown that teaching is regarded as a complex system (Casey, Gentile, \& Bigger, 1997). This complexity is linked to a number of variables involved and the links among them, to the time framework in which teaching is carried out and to the relational (teacherstudent), disciplinary, social and cultural background (Lawn, 1991). 'A Japanese saying states that a statue of the Buddha is worthless if the person who carved it did not put his soul into it' (Imai, 2001). Ultimately, if the approaches aimed at improving the quality of teaching focus on individual parts, there is the risk of generating a mere quality 'certificate': a statue. With reference, for example, to the dynamic aspect of teaching, some authors highlight how, making assessments on the quality of teaching at isolated time instants, disconnected from the processes in progress, cannot allow us to have a vision of the whole, but only of that instant; it will hardly be able to offer

\footnotetext{
${ }^{3}$ We do not want to enter the debate on the concept of customer by referring to the existing literature (Becket \& Brookes, 2006).

${ }^{4}$ Board of Directors, Academic Senate, 2018.

${ }^{5}$ Verna I., D., A Public act filed with a notary of the Italian Republic, 2017.
} 
significant feedback on improvement (Owlia \& Aspinwall, 1996; Marsh \& Roche, 1997).

Fig.1 A holistic approach to higher education: L'Ascolto

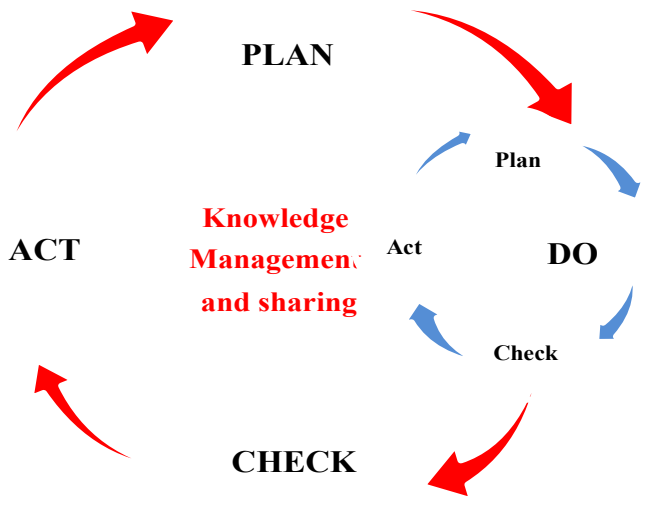

The specific context (i.e. needs that emerge from the social, cultural, university environments, etc.) represents a further element that conditions the quality of teaching (Lawn, 1991; Carptner, \& Tait, 2001). Although studies have been developed that consider the dynamics of processes in their context (Barone \& Lo Franco, 2009; Verna, 2008; Verna, 2012; Chen et al, 2014), there are no approaches that consider the overall educational processes (Degree Courses and individual subjects) and the human resources involved (systemic aspect) that change during the time in which the teaching takes place (dynamic aspect). It is necessary to consider the relationships between teaching, research and the development of the social context. In the literature the need for a holistic approach to higher education is highlighted (Sakthivel $\&$ Raju, 2006) and there are numerous studies that address these issues (Horine \& Hailey, 1995; Burkhalter, 1996; Barnard, 1999). There is, however, the need to address the broader management context of institutions, and not, therefore a 'partial holistic' (Mantos et al, 2017). L'Ascolto, anchored in the culture of quality (Horine \& Hailey, 1995; Herguèner \& Reeves, 2000), attempts to fill this gap, through a holistic approach to higher education.

\section{'Doing the right things': Listening to the needs}

In a holistic approach to higher education 'doing the right things' can be rendered operational by simply listening to the emerging needs from one's own context: teachers, students, stakeholders, institutional bodies (Kanji et all, 1999) and adapting them to an appropriate academic program. Meeting the requirements of a TQM approach means, first of all, listening to the customer's voice (Pitman et al, 1996; Sa \& Saraiva, 2001). In reference to the lecturer, the most widespread listening tools do not consider the temporal aspect in which 
the teaching is carried out. In general they do not consider the implications deriving from the complexity of teaching, such as peer evaluation on site (Marsh \& Roche, 1997; Owlia \& Aspinwall, 1996) or reflective and selfassessment practices (Selding, 1999; Watson, 1999; Kane et all, 2004) such as the teaching portfolio (Selding, 1991). Also, the student satisfaction test (Aleamoni, 1999) does not consider the work of the instructor throughout the course. In reference to the student, the most widespread listening tool is the student satisfaction test. There is a vast literature on student satisfaction questionnaires and their usefulness (Worthington, 2002) although this is debatable (Kember et all, 2002; Nasser \& Fresco, 2002). However, it is evident that the most significant shortcoming is not to consider the training needs of students in relation to the needs of all other clients, to the processes in progress and to the relationships among them - considered as a single whole (systemic and dynamic aspect). The same considerations can be applied to institutional bodies and stakeholders. In this sense, listening to the needs of students (Zineldin et all, 2011), should be linked to the listening of instructors (Rosa, Tavers, \& Amarl, 2006), of employers (Willis \& Taylor, 1999; Rodman et al ., 2013) and institutional bodies, as integral parts of a context (A.Mutti-Assaf et all, 2013). There is a clear need for a plurality of information sources (listening) to capture the complexity of teaching (Hoyt \& Pallet, 1999). In the literature there are numerous studies that highlight the need for pluralistic approaches (Roche \& Marsh, 2000). In this sense, TQM has found wide application in higher education (Owlia \& Aspinwal, 1998; Kanji \& Tamby, 1999). L'Ascolto, based on the philosophy of the TQM, uses a plurality of tools to listen to the needs of all the clients and this listening, in turn, is embodied in degree programs and individual, subjects in order to steer the teaching processes towards continuous improvement (Cardona Mora 2014).

\section{'Doing the things right': Satisfying the needs}

In a holistic approach to higher education, 'doing things right' can be translated into the continuous improvement of all teaching processes. In TQM, the continuous improvement of processes is carried out by the PDCA Cycle (Plan, Do, Check, Act) of Deming (Deming 1951). Applying the Deming Cycle to teaching processes (Filtz-Gibbon, 1997), it is possible to link the continuous listening to one's own context (needs), to the planning, management, evaluation and improvement of the degree course and the individual subjects that compose it. In the literature there are studies that apply the Deming Cycle to individual subjects (Verna, 2008; Verna, 2012; Barone \& Lo Franco, 2009; Chen et al, 2014). However, in this perspective, there is a lack of studies on the application of the PDCA to the entire, degree program, in its systemic relationships and to the perspective of satisfying the needs of all customers (holistic approach). To this end, L'Ascolto applies the Deming 
Cycle to training processes, creating integrated multiple PDCA cycles of various levels. The L'Ascolto approach places the focus on listening to the needs of the clients, initially, in itinere and at the end (learning outcomes) of the single subjects and the entire degree course. In this context, the PDCA applied to teaching processes, favors a system of management and sharing of knowledge that links listening to the needs of all customers, to the knowledge of fundamental processes, to their structure and their linking relationships- for the full satisfaction of needs (fig.1).

\section{The L'Ascolto Approach: PDCA and QFD for the Continuous Improvement of Higher Education}

As noted, L'Ascolto applies Deming's PDCA to all educational programs (Degree Course - DC and individual subjects), creating a holistic approach to higher education. The PDCA cycles in L'Ascolto are two and closely related: PDCA1 (DC) and PDCA2 (individual courses). The figures presented below even though distinctly different (fig.2, fig.5, fig.10) offer a multidimensional representation of the holistic approach that characterizes L'Ascolto. Fig. 2 shows how listening to stakeholder needs are deployed as DC targets, at the same time unveiling how the mentioned targets are related to the hearing of specific students' training gaps . Fig.5 shows how (at the same time) the needs of instructors are also listened to. In particular, the instructor who plans, manages, evaluates and improves his own course (PDCA2), reinforces a systematic and structured system of knowledge management and sharing (best practices). In turn, the learning outcomes portray the instructor's academic professionalism, at the same time ameliorating the instructor's curriculum. Fig. 10 finally shows, as compared to this broader context of targets, needs and learning outcomes, in which the PDCA1 and PDCA2 cycles are implemented. The needs of institutional bodies are also listened to and satisfied. These needs are met thanks to the knowledge management and sharing system that integrates research into educational processes, thus nurturing a virtuous circle of continuous improvement, the quality of teaching, research in training and the cultural development of the social context - as later illustrated. This is the holistic approach on which the $L$ 'Ascolto is based, which is illustrated below, starting from the presentation of the PDCA1 (fig.2).

The PDCA1 and listening to the needs of the contest (needs-target-learning outcomes). 


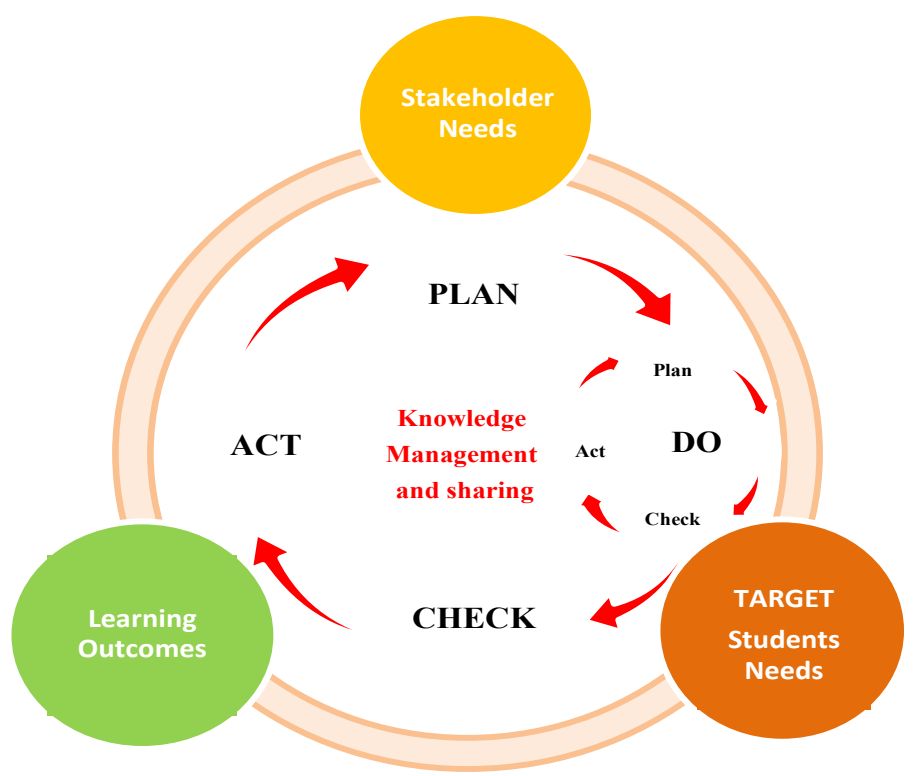

PDCA1: Continuous Improvement of Degree Courses

\section{The Plan Phase}

The Plan Phase of the PDCA1 corresponds to the planning of an educational program in its fundamental aspects. To this end, L'Ascolto integrates a plurality of instruments for listening to the needs of stakeholders (i.e. tests, sector studies, statistics) into a degree course through the actions of Quality Function Deployment - QFD (Akao, 1990). QFD is a system to translate customer needs into appropriate internal company specifications at every stage of the product development cycle, starting from research through design and engineering, production, distribution, installation and marketing, sales and technical assistance (American Supplier Institute - ASI, 1987).

The QFD was widely applied in higher education. For example, with respect to the identification of more appropriate teaching techniques for the achievement of educational objectives (Lam \& Zhao, 1998) or with reference to the capacity of a university curriculum to meet customer needs (Bier \& Cornesky, 2001). In particular, in the L'Ascolto the QFD1 (fig.3) is used by an institutional body (i.e. didactic commission - TC) to identify the relationship between the general objectives of a degree course integrated by listening to stakeholders, (Bloom taxonomy - Bloom et all, 1956), with the disciplines that make them possible (Verna, 2014). The legend at the edge of the matrix establishes the terms of this relationship: + stronger; - average; $\mathrm{x}$ weak. The matrix intersection highlights which disciplines best meet certain objectives (strong relationship). 
Figure 3. The QFDI

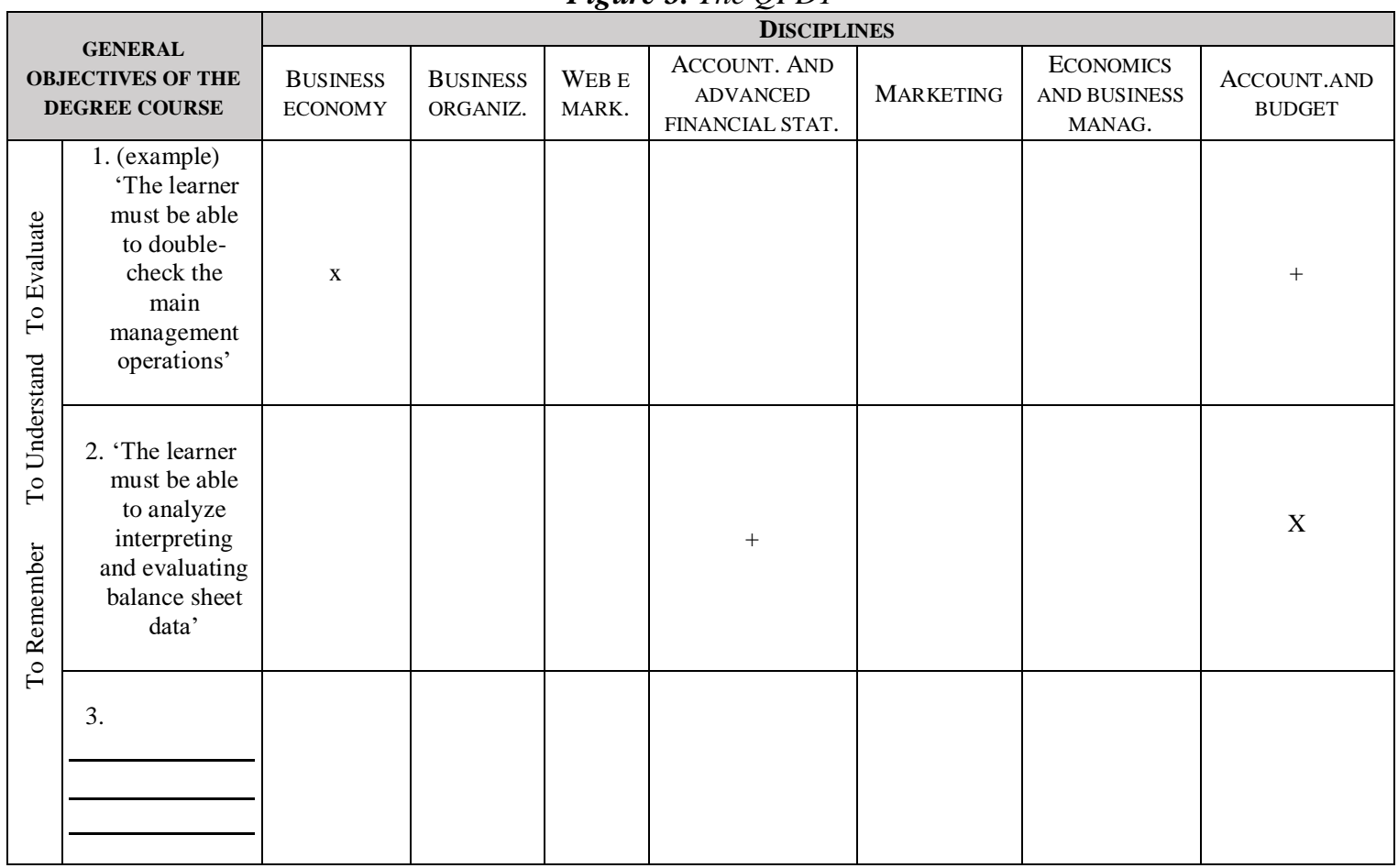

\begin{tabular}{|c|c|}
\hline Sign / value & $\begin{array}{c}\text { Type of } \\
\text { relationship }\end{array}$ \\
\hline+5 & STRONG \\
\hline-3 & $A V E R A G E$ \\
\hline $\mathrm{X} 1$ & WEAK \\
\hline
\end{tabular}

The QFD2 (fig.4) allows the TC to complete listening and translation of stakeholder needs, with soft skills. The latter, in QFD2, are related to listening to students' needs. This brings together the needs of stakeholders and students. In particular, in the top line the disciplines defined in QFD1 and in the columns, the soft skills and the corresponding needs of the students are reported. These needs are measured through an entry test and translated into a scale from 0 to 10 , where 0 indicates the absence of training needs and 10 indicates the maximum need. Also, in this case, the crossing of the matrix clarifies which disciplines more than others are suitable to develop one or more soft skills and which students' needs corresponds to it. Multiplying the need value by the value corresponding to the matrix intersection, we obtain the weight of a discipline in the development of one or more skills, with respect to the need expressed by the students. The assessment of the training needs of students is repeated at the end of a DC, in order to verify the development of these skills. The degree course is defined in its fundamental components. The TC, sends to all the teachers of the DC the general targets 
(and the soft skills) of the respective subjects. The Plan Phase of the PDCA1 is completed and the Do phase is started.

Figure 4. The QFD2

\begin{tabular}{|c|c|c|c|c|c|c|c|c|}
\hline & \multirow{2}{*}{\multicolumn{7}{|c|}{ DISCIPLINES }} \\
\hline & & & & & & & & \\
\hline $\begin{array}{c}\text { 'CRITICAL' } \\
\text { AND SPECIFIC } \\
\text { COMPETENCES }\end{array}$ & $\begin{array}{c}\text { LEARNING } \\
\text { NEEDS } \\
\text { (ENTRY } \\
\text { TEST) }\end{array}$ & $\begin{array}{l}\text { BUSINESS } \\
\text { ECONOMY }\end{array}$ & $\begin{array}{l}\text { BUSINESS } \\
\text { ORGANIZ. }\end{array}$ & $\begin{array}{l}\text { WEB } \\
\text { E } \\
\text { MARK. }\end{array}$ & \begin{tabular}{|c} 
ACCOUNT. \\
AND \\
ADVANCED \\
FINANCIAL \\
STAT. \\
\end{tabular} & MARKETING & $\begin{array}{c}\text { ECONOMICS } \\
\text { AND } \\
\text { BUSINESS } \\
\text { MANAG. }\end{array}$ & $\begin{array}{l}\text { ACCOUNT.AND } \\
\text { BUDGET }\end{array}$ \\
\hline $\begin{array}{l}\text { Analysis and } \\
\text { solution of } \\
\text { problems }\end{array}$ & 8 & & + & & + & + & + & + \\
\hline Critical thinking & 9 & & - & - & + & - & - & - \\
\hline Exhibition skills & 10 & $\mathrm{x}$ & - & & - & + & + & $\mathrm{X}$ \\
\hline $\begin{array}{c}\text { Analytical } \\
\text { reasoning }\end{array}$ & 9 & - & $\mathrm{x}$ & & - & & & $\mathrm{X}$ \\
\hline Teamwork & 9 & - & + & + & & + & $\mathrm{x}$ & \\
\hline $\begin{array}{l}\text { Interpersonal } \\
\text { skills }\end{array}$ & 9 & & + & - & & + & & \\
\hline & Totale & 67 & 199 & 107 & 142 & 257 & 126 & 86 \\
\hline
\end{tabular}

Phase Do

The Do Phase corresponds to the start of the single courses comprising the DC, i.e. the PDCA 2 is activated for each course. The conclusion of a DC will initiate the Check Phase.

\section{Check and Act Phases}

In the Check Phase, students have completed their studies and are required to do a test to evaluate soft skills - disciplinary skills are assessed on entry, in progress and at the end of the individual subjects of the DC. If the TC detects unsatisfactory learning outcomes, it will consult the PDCA2 knowledge management and sharing system.

This system (based on language: needs - target - learning outcomes) uses, in a systemic, dynamic and contextual way, a plurality of listening and satisfaction tools for teachers and students (as illustrated in the presentation of the PDCA2). Ultimately, the TC checks the Check and Act phase of the PDCA2 to assess any corrective actions put in place by the teachers (if and what corrective actions have been implemented and with what results) and the correct management by the teachers of the PDCA2. The latter, in fact, if implemented correctly, allows the teacher's self-training by sharing the best practices of colleagues who operate in the same context (needs - target learning outcomes). In relation to the results of the Check phase, the TC will define the most appropriate actions.

The close relationship that links the two cycles (PDCA1 and PDCA2) explains their sequence and the reason why PDCA2 is indispensable for a better understanding of the Check and Act Phases of the PDCA1. 


\section{PDCA2: Continuous Improvement of Each Course}

Fig. 5 shows how, the targets defined in the PDCA1 are articulated by the teachers of the courses, in target of the course modules and related to the educational needs (in input) and to the learning outcomes (in progress and outgoing) that students show in respect to these targets. The needs of the students are expressed in terms of 'level of homogeneity' (upwards or downwards) or heterogeneity that the class of students had in input (needs) or that they acquired in itinere and in output (learning outcomes). Compared to this context of targets, needs and learning outcomes, the teacher shows his own educational needs, fig.5.

In particular, teachers' educational needs are taken into consideration through tools (teacher self-assessment and student satisfaction tests) that monitor 'key processes' of teaching quality, in a specific context. In the literature we refer to the teaching quality building blocks (Probst et al., 2002; Ramsden, 2003) that some authors have organized into ten constellations (Chen et al, 2014). In this study, 'key processes' such as the design, management, evaluation and improvement of teaching quality are an integral part of the L'Ascolto approach (PDCA1 and PDCA2). Furthermore, within the teaching management process (phase Do), some 'control areas' linked to the quality of teaching are monitored, such as: disciplinary, communicative and relational skills and teaching strategies. These areas of control can be extended in relation to the professional development of the teacher in its context (satisfaction of the training needs of the teacher - self-training).

Fig.5 The PDCA2: listening to and meeting the needs of the context

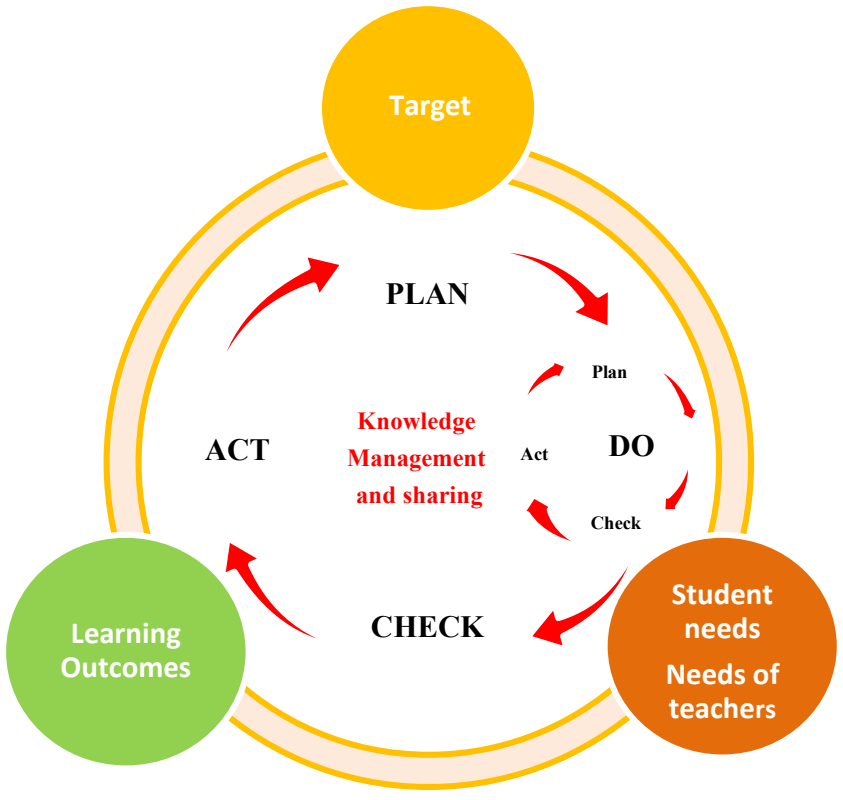




\section{Plan Phase}

In the Planning Phase, the teacher uses QFD 3 (Fig. 6) to identify, first of all, the relationship between the targets of the modules and the related educational needs of the learners. These needs are taken into consideration using entrance tests (disciplinary preconceptions) and reported in the QFD3 with the same modalities seen previously (QFD2). In relation to these, the most effective teaching strategies are identified (top row, fig. 6).

Teaching strategies are combinations of methods, tools and teaching time. An example is provided in fig. n. 7 (Verna, 2014).

In L'Ascolto, the best practices of a teacher are standardized with respect to its context and to the 'control areas', in two standardization sheets of the teacher's professionalism: STP1s and STP2, fig. 8 and 9. In STP1s teaching strategies are standardized which allowed a teacher to reach the highest learning outcomes (homogeneity of the class in progress or outgoing i.e. $98 \%$ ) with respect to specific targets and related needs (level of homogeneity / heterogeneity of the incoming class). In STP2 the communication and relational techniques and disciplinary competences that have allowed the teacher in the same context to achieve these results are standardized. STP1 and STP2 are useful to the teacher in all phases of the PDCA2, as highlighted in the Check Phase that follows. 
Fig.6 $Q F D 3$

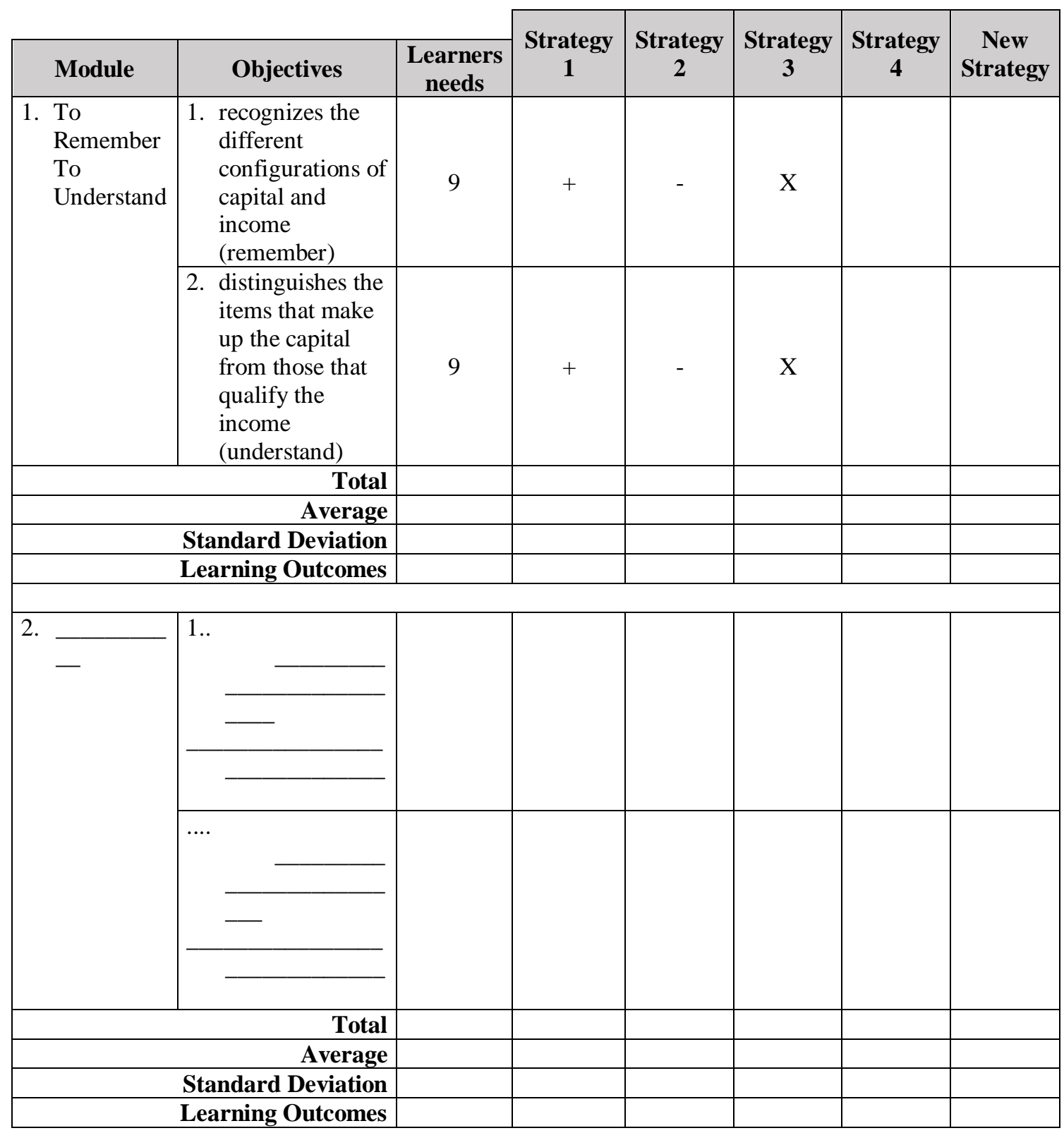

\begin{tabular}{|c|c|}
\hline Sign/value & Kind of relationship \\
\hline+5 & STRONG \\
\hline-3 & AVERAGE \\
\hline $\mathrm{X} 1$ & WEAK \\
\hline
\end{tabular}


Fig. 7 Example of Accounting Strategies

\begin{tabular}{|c|l|}
\hline STRATEGIES & \multicolumn{1}{|c|}{ METHODS } \\
\hline Strategy 1 & $\begin{array}{l}\text { Class / tutorial } \\
\text { (explain, demonstrate, perform) }\end{array}$ \\
\hline Strategy 2 & $\begin{array}{l}\text { Role playing/ tutorial/lclass } \\
\text { (demonstration - stimulus, perform, discuss, explain) }\end{array}$ \\
\hline Strategy 3 & $\begin{array}{l}\text { Case / class } \\
\text { (perform, discuss, explain) }\end{array}$ \\
\hline Strategy 4 & $\begin{array}{l}\text { Project work / class } \\
\text { (perform, discuss, explain) }\end{array}$ \\
\hline Strategy 5 & $\begin{array}{l}\text { class/ self-study/questionnaire (or closed case) } \\
\text { (demonstration, perform, discuss, explain) }\end{array}$ \\
\hline Strategy 6 & $\begin{array}{l}\text { class/questionnaire/class (or closed case) } \\
\text { (explain, perform, discuss, summarize) }\end{array}$ \\
\hline
\end{tabular}

In particular, in this Plan Phase, the teacher, with respect to the different targets / needs, will be able to identify his/her own strategies (new strategy) or make a choice among those proposed by STP1 reporting them in the QFD3 (strategy line, fig. 6). In this case, we will proceed, as already seen, to the QFD2 matrix. Observe how the last line of each module highlights the weight of the strategies with respect to the targets / needs of each module - just as the last row of the matrix highlights the prevailing strategies with respect to the target / needs of the course. At this point, the teacher is ready for the lesson implementation phase (Do). 
Fig. 8 STP1 Standardization of the Teacher's Professionalism

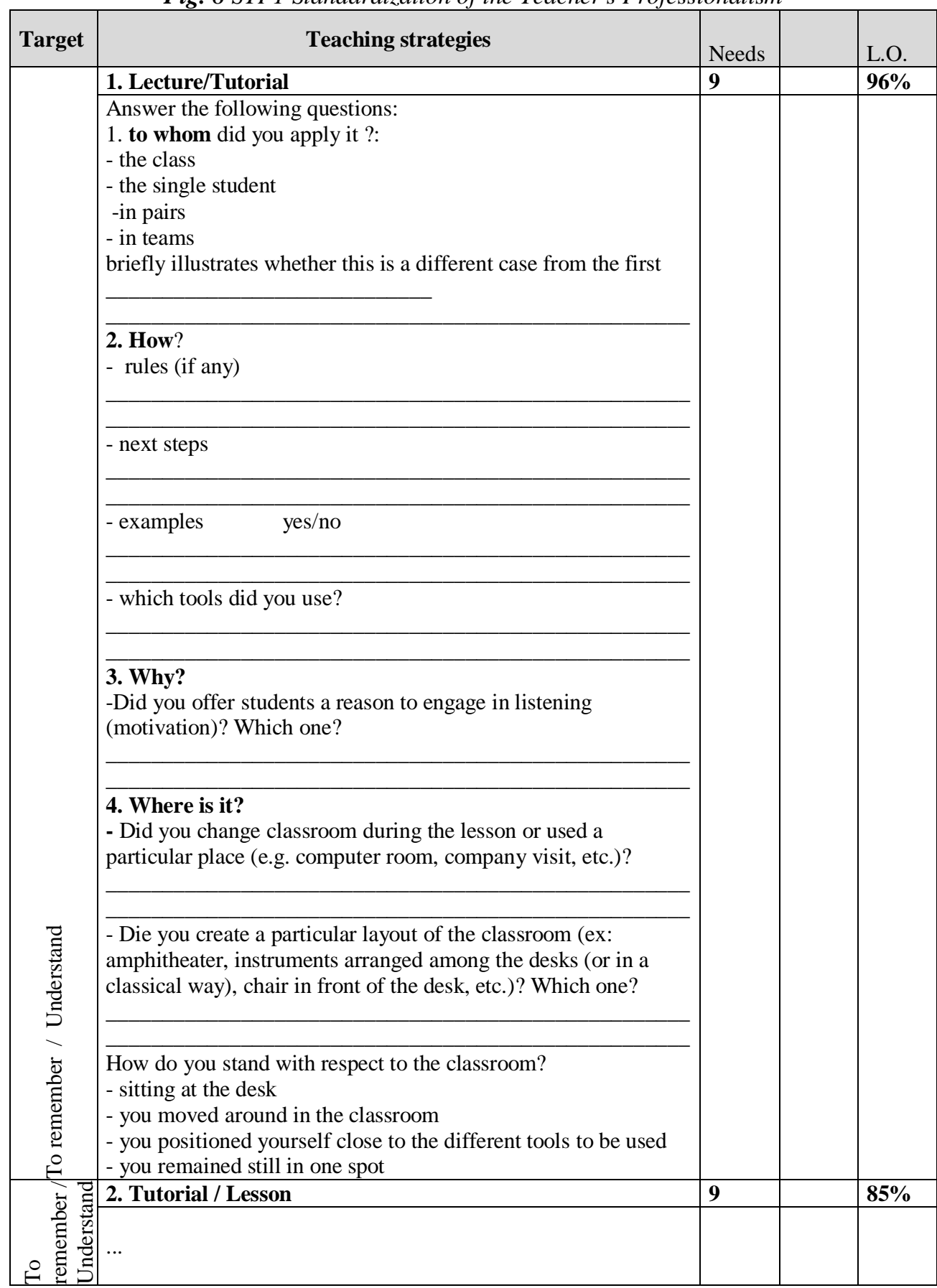


Fig. 9 STP2 Standardization of the Teacher's Professionalism.

STP2

Sectrion 1 .

\section{COMMUNICATION AND RELATIONAL TECHNIQUES}

Emerged problems

1. Report in the following table the problems that emerged in the communication (verbal, non-verbal) and in the relationship with the students (self-assessment / lecturer and qualitative / student test) noting, in the respective boxes, the test questions / questions that highlight these problems

2. Briefly describe the solutions adopted and the level of learning achieved

Course of Objective module $n$.

L.O.

\begin{tabular}{|l|l|l|l|}
\hline $\begin{array}{l}\text { Verbal } \\
\text { Communication }\end{array}$ & $\begin{array}{l}\text { Non verbal } \\
\text { Comunication }\end{array}$ & Use of the space & $\begin{array}{l}\text { Relational } \\
\text { aspects }\end{array}$ \\
\hline 1. & 1. & $\begin{array}{l}1 . \quad \begin{array}{l}\text { (example: question 1 } \\
\text { teacher ... after having } \\
\text { prepared the space I use it })\end{array} \\
\ldots\end{array}$ & $\ldots$ \\
\hline \multicolumn{2}{|c|}{ Proven solution } & $\mathbf{1}$ \\
\hline
\end{tabular}

Example (problem / use of the space):

I position the instruments (blackboards, billboards, lecture notes, projectors, etc.) in different points of the classroom, so that everyone can see them and I can move myself to use them. I place amphitheater benches and place a blackboard (or projector or other) in the center. I organize the lesson in a classroom without desks for a team work (business game).

Learning Outcome: (L.O.) (example: $78 \%$ )

\section{No problems emerged}

Briefly describe your communicative / relational style by offering one or more examples

Communication / relational style

Verbal:

Non verbal:

Use of the space:

Relational Aspects:

Section 2.

Content and their organization

Course of Objective module n. L.O.

Content

Organization of the contentes 


\begin{tabular}{|l|l|}
\hline 1. & $\begin{array}{l}1 . \quad \text { (example: question 1 teacher } \\
\text {...after setting up the space I use it) }\end{array}$ \\
\hline$\ldots$ & $\ldots$ \\
\hline $\begin{array}{l}\text { Example: } \text { use of a management software for accounting and budget courses; } \\
\text {..........tutorial with real documents (e.g. invoices, etc.) }\end{array}$ \\
\begin{tabular}{l} 
I enclose the design of the form No.__ relative to the __ course of the A.A. \\
\hline
\end{tabular} \\
Learning Outcomes: (L.O.) (example: $89 \%)$
\end{tabular}

\section{The DO Phase}

In this phase the teacher implements the lessons of each module, in relation to the design carried out. At the end of each module (last lesson), the Check Phase is activated.

\section{Check Phase}

In the L'Ascolto the Check Phase has the function of gathering information (listening) for the purposes of improvement (Act). In this sense, the last day of lecture relative to the first module (and to the following modules), the teacher administers to the students an end of module test-TFM, to be filled in anonymously. The test focuses on verifying the achievement of the targets (fundamental) of the reference form. This test allows the teacher to verify the educational needs of the students in itinere and at the end of the course (learning outcomes) and enables the students to become aware of their academic performance. The outcome of the test can be positive or negative. In the event of a positive outcome, there is a class of students that has exceeded the learning threshold established by the teacher (e.g.: $60 \%$ of the class of students has positive learning outcomes - class homogeneity upwards). This threshold is established from time to time depending on the learning outcomes achieved by teachers in the same context conditions. The positive learning outcomes allow the teacher to standardize the best practices with reference to the control areas, in STP1s and STP2. Standardization is carried out by the teacher who answers specific questions present in STP1 and STP2. This allows the sharing of knowledge among teachers who operate in the same context conditions. The importance for a teacher to receive information on the aspects that are most connected to the professional development of a course is obvious (Loden, 2000). In the case of a negative outcome of the TFM, the teacher reflects on the possible causes of such learning outcomes by 'listening' to his/her own educational needs. The listening is carried out through two tests: course satisfaction (administered to students together with the TFM) and of teacher self-assessment. These tests focus on the 'control areas' and contain questions of the same type, in order to push the teacher to reflect on the possible difference between his own self-assessment and that of the student, 
in the same 'control areas'. In this way, the needs of teachers are related to those of students (needs and learning outcomes) and stakeholders (target). Ultimately, the distance between listening to stakeholder and student needs and their satisfaction (target achievement) can be filled by listening to and satisfying teachers' training needs (fig. 5). In this sense the research can offer a significant contribution through the integration / replacement and / or elimination of questions in the tests (evaluation / self-evaluation and approval) and in STP1 and STP2 for the continuous self-training of the teacher. Observe how each teacher administers in his / her course, students, input assessment (needs), learning (learning outcomes) tests, and the teacher compiles a selfassessment test and answers the questions of STP1 STP2 (standardization). It is emphasized that such information derives from the processes in progress and from the relationships that link these processes to listening to the needs emerging from its context. The importance of this type of information is crucial for the development of research in the field of education and for the contribution that this can offer to education for improvement vs innovation (fig.10). Ultimately, an approach is proposed which is linked to empowerment evaluation (Fetterman, 2003) or collaborative evaluation also defined by some authors as participatory evaluation (Cousins, 2003). The participatory model is based on principles such as the active participation of the actors involved (evaluators and evaluators act in collaboration to increase the validity, in qualitative and quantitative terms, of the assessment itself). In this regard, Scriven $(2003,15-30)$ observed that the evaluation acts in terms of description of the facts and not as a value judgment on the same. In this sense, the results of this evaluation/self-assessment phase (Check) feed into the Act Phase.

Fig. 10 The L'Ascolto approach: listening to and meeting the needs of the context

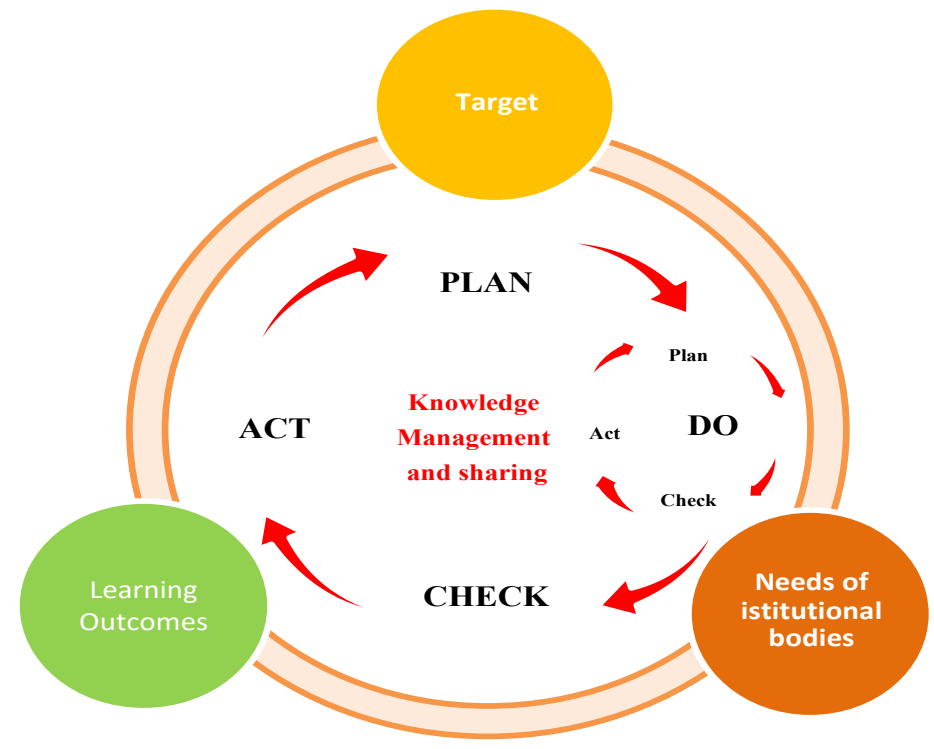




\section{Act Phase}

Once the Check Phase is completed and the learning threshold is not reached, the Act phase is activated. The teacher can choose whether to adopt the best practices of his colleagues (in the same context conditions), present in STP1 and STP2 or experiment new corrective actions (new Strategy, fig.6). In relation to this, the teacher modifies the QFD3 and the TFM (second module), in relation to the targets not reached - a process that is repeated in the subsequent modules, in relation to the importance of the target not reached. In this sense, the satisfaction of the teacher's needs, in L'Ascolto, is realized when, in a specific context of target-needs and learning outcomes (Plan, Do), the teacher evaluates the distance between the learning outcomes of the students in itinere and the target (Check) and identifies 'critical areas' on which to act to reduce or cancel this distance - or choose the best practices of a teacher in the same context (Act). The repetition of the PDCA2 cycles (Phase Do of the PDCA1) inform the PDCA1 on the results achieved (target-learning outcomes) and on the methods of achieving these results (standardized best practices). Ultimately, a continuous circuit of: design, management, evaluation and improvement of all training processes (PDCA1 and PDCA2) is realized. In this sense, it implements a 'cultural revolution' of the whole context: student training, teacher self-training (quality of teaching), development of research in training and cultural development of the social context, thus also satisfying the needs of institutional bodies (fig.10).

\section{Conclusions}

As discussed throughout the manuscript, L'Ascolto is a holistic approach to Higher Education. In a complex and ever-changing education system, it is necessary to consider people needs, teaching processes, tools and techniques as a whole integrated system. In this sense the management and sharing of knowledge derive from a systemic, dynamic and contextual approach to teaching, which permits the satisfaction of the needs of either the instructors, and students, as well as of stakeholders and institutional bodies. Further, L'Ascolto attempts to improve the quality of research in the training field and its systemic relationships.

Although the model derives from experiments carried out over the years in an interdisciplinary way, further studies will be necessary to study the application of the model in its entirety.

\section{References:}

1. Akao, Y., Ed. (1990). Quality Function Deployment: Integrating Customer Requirements into Product design. Productivity Press. Cambridge, MA. 
2. Aleamoni, L.M. (1999). Student rating myths versus research facts from 1994 to 1998. Journal of Personnel Evaluation in Education, 13 (2):153-166.

3. Barnard, J. (1999). Using total quality principles in business courses: The effect on student evaluations. Business Communication Quarterly, 62(2), 61-73.

4. Barone, S., \& Lo Franco, E. (2009). Design of a university course quality by teaching experiments and student feedback (TESF). Total Quality Management \& Business Excellence, 20(7), 687-703.

5. Becket, N., \& Brookes, M. (2006). Evaluating Quality Management in University Departments. Quality Assurance in Education, 14(2), 123 142.

6. Bier, I.D., \& Cornesky, R. (2001). Using QFD to construct a higher education curriculum. Quality Progress, 4, 64-68.

7. Bloom, B. S., Engelhart, M. D., Furst, E. J., Hill, W. H., \& Krathwohl, D. R. (1956). Taxonomy of educational objectives: The classification of educational goals. Handbook I: Cognitive domain. New York: David McKay Company.

8. Burkhalter, B. B. (1996). How can institutions of higher education achieve quality within the new economy? Total Quality Management 7, 153-160.

9. Cardona Mora, J.N. (2014) Continuous improvement strategy, European Scientific Journal, 10 (34):117-125.

10. Carptner, B., \& Tait, G. (2001). The rhetoric and reality good teaching: a case study across three faculties at the queensland University of Technology. Higher Education, 42(2): 191-203.

11. Casey, R.J., Gentile, P., \& Bigger S.W. (1997). Teaching appraisal in Higher education: An Australian prospective. Higher Education, 34(4): 459-482.

12. Chung-Yang Chen, Pey-Chi Chen \& Pei-Ying Chen, (2014). Teaching quality in higher education: An introductory review on a processoriented teaching-quality model. Total Quality Management and Business Excellence, 25 (1-2): 35-56.

13. Conti, T. (2004), Qualità un'occasione perduta? Guida provocatoria per imprenditori, manager e amministratori che mirano all'eccellenza. Etas, Milano, 2004, p.12.

14. Cousins, J.B., (2003). Utilization effects of participatory evaluation, in T. Kellaghan, D.L. Stuffebleam (Eds.), International Handbook of Educational Evaluation, Kluwer Academic Publisher, Dordrecht, pp. 245-265. 
15. Deming, W.E., 1951. Elementary principles of the statistical control of quality. Nippon Kagacu Gigutsu Remmei: Japanese Union of Science and Engineering (JUSE).

16. Feingembaum, A.V. (1956). Total Quality Control. Harvard Business Review, Boston, 11-12.

17. Fetterman, D. (2003). Empowerment evaluation strikes a responsive cord, in Donaldson, S.I., \& Scriven, M. (Eds), Evaluating social programs and problems. Lawrence Erlbaum Associates Publishers, Mahwah, N.J., pp. 63-76.

18. Fitz-Gibbon, C. T. (1997). Will *joy' in work be helped or hindered by value-added indicators? Applying Deming to education. Total Quality Management, 8, 152-155

19. Herguner, G., \& Reeves, N.B.R. (2000). Going against the national cultural grain: a longitudinal case study of organizational culture change in Turkish higher education. Total Quality Management, 11(1), 45-56.

20. Horine, J. E., \& Hailey, W. A. (1995). Challenges to successful quality management implementation in higher education institutions. Innovative Higher Education, 20(1), 7-17.

21. Hoyt D., \& Pallet W. (1999). Appraising teaching effectiveness: Beyond student ratings. IDEA Paper n.36. Centre for Faculty Evaluation and Development, Kansas State University, Manhattan.

22. Imai, M. (2001). Gemba Kaizen come ottenere crescita e profitti con l'innovazione continua. Il Sole 24Ore, Milano, 2001.

23. Juran, J. M. (1962). Quality Control Handbook. Mc Graw-Hill, New York.

24. Kane, R., Sandretto S., \& Heath C. (2004). An investigation into excellent tertiary teaching: Emphasizing reflective practice. Higher Education, 47(3): 283-310.

25. Kanji, G.K., Malek, A., \& Bin A. Tambi (1999). Total Quality Management in UK higher education institution. Total Quality Management\& Business excellence, 10(1): 129-153.

26. Kember, D., Leung, Y.P., \& Kwan K.P. (2002). Does the use of student feedback questionnaires improve the overall quality of teaching. Assessment \& evaluation in Higher Education; 27: 411-425.

27. Lam, K. \& Zhao X. (1998). An application of quality function deployment to improve the quality of teaching. International Journal of Quality \& Reliability Management, 15(4), 389-413.

28. Lawn, M. (1991). Social construction of quality on teaching. Evaluation and research in Education, 5 (1-2), 62-77. 
29. Louden, W. (2000). Standards for standards: The development of Australian professional standards for teaching. Australian journal of Education, 44(2), 118-134.

30. Mantos, J., Sarrico, C.S. \& Rosa M.J. (2017). The integration of quality management in higher education institutions: a systematic literature review. Total Quality Management, 28 (2), 159-175.

31. Marsh, H.D., \& Roche, L. A. (1997). Making students' evaluations of teaching effectiveness effective: The critical issue of validity, bias, and utility. American Psychologist, 52, 1187-1197.

32. Mutti-Assaf, A., et al (2013), The process of continuous development (improvement) and its effects on organizational performance in the department of lands and survey, European Scientific Journal, 9 (13):418-432.

33. Nasser, F., \& Fresco B. (2002), Faculty views of student evaluation of college teaching. Assessment \& Evaluation in Higher Education, 27 (2): 187-198.

34. Owlia, M.S., \& Aspinwal E.M. (1998). Application of quality function deployment for the improvement of quality in engineering department. European Journal of Engineering Education, 23(1): 105-125.

35. Owlia, M.S. \& Aspinwall E.M. (1996). Quality in higher education a survey. Total Quality Management and Business Excellence, 7(2), 161-171.

36. Pitman, et al, (1996). QFD application in educational setting, International Journal of Quality and Reliability Management, 13(4), 99-108.

37. Pitman, G., Motwani. J., Kumar, A., \& Cheng, CH (1996). QFD application in an educational setting: A pilot field study. International Journal of Quality \& Reliability Management, 13(4):99-108.

38. Probst, G., Raub, S., \& Romhardt, K. (2002). Managing knowledge: Building blocks for success. New York, NY: John Wiley \& Sons Ltd.

39. Quinn, A., Lemay, G., Larsen, P., \& Johnson, D.M. (2009). Service quality in higher education. Total Quality Management \& Business Excellence, 20(2), 139-152.

40. Ramsden, P. (2003). Learning to teach in higher education. New York, NY: Taylor \& Francis Group.

41. Roche, L., \& Marsh H.W. (2000). Multiple dimensions of university teacher self-concept. Construct validation and the influence of students' evaluation of teaching. Instructional Science, 28(5): 439468.

42. Rodman, K., Biloslavo, R., \& Bratoz, S. (2013). Istitutional quality of a higher education institution from the prospective of employers. Minerva, 51(1), 71-92. 
43. Rosa, M.J., Tavers D., \& Amarl A. (2006), Institutional consequences of quality assessment. Quality in higher education, 12(2), 145-159.

44. Sà, P.M., \& Saraiva, P. (2001). The development of an ideal kindergarten through concept engineering/quality function deployment. Total Quality Management, 12(3), 365-372.

45. Sakthivel, P. B., \& Raju, R. (2006). Conceptualizing total quality management in higher education. The TQM Magazine, 16(2), 145159.

46. Sargiacomo, M. (1999). Antichi valori e nuovi strumenti gestionali per migliorare la qualità nel sistema universitario: una proposta per il CUEIM in Sinergie, n. 49, pp. 207-230.

47. Scriven, M., (2003). Evaluation theory e metatheory, in T. Kellaghan, D.L., \& Stuffebleam (Eds.), International handbook of Educational Evaluation, Kluwer Academic Publishers, Dordrecht, pp. 15-30.

48. Selding, P. (1991). The teaching portfolio. A practical guide to improved performance and promotion/tenure decisions. Bolton, Ma: Anker.

49. Selding, P. (1999). Self-evaluation: what works? What doesn't? in P.Selding e ass., Changing practices in evaluating teaching. Bolton, Ma: Anker.

50. Verna, I., (2008). La progettazione di un intervento didattico in Economia Aziendale. Roma, Aracne Editrice.

51. Verna, I., \& Perozzi, D. (2010). The Deming cycle in university teaching. The TEM Model (Teaching Evaluation Model). Poster, American Accounting Association.

52. Verna, I. (2012). Il ciclo di Deming nella didattica universitaria, Il Teaching Evaluation Model TEM. Roma, Aracne Editrice.

53. Verna, I. (2014). The Quality Function Deployment and the customer satisfaction. The case of universities. European Scientific Journal, Special Edition, 8 (189-202).

54. Verna, I., \& Lucianetti L. (2014). Continuous Improvement in the University Teaching: the TEM Model. European Scientific Journal Special Edition, 1 (2), 480-505.

55. Verna, I., \& Perozzi D. (2014). Applying TEM Model (Teaching Evaluation Model) in Academic course in accounting: a comparison across five years. European Scientific Journal Special Edition, 1 (6), 330-344.

56. Watson, M.E. (1999). A goal oriented, self-evaluation model for annual review of faculty in higher education. International Journal of Reality Therapy, 18, 35-41. 
57. Willis, T.H., \& Taylor, A.J. (1999). Total quality management and higher education: the employers' perspective. Total Quality Management \& Business Excellence, 10(7), 997-1007.

58. Worthington, A.C. (2002). The impact of student perceptions and characteristics on teaching evaluations: a case study in finance education. Assessment \& Evaluation in Higher Education, 27, 49-64.

59. Zineldin, M., Akdag, H.C. \& Vasicheva, V. (2011). Assessing quality in higher education: new criteria for evaluating students' satisfaction. Quality in higher education, 17(2), 231-243. 